\title{
Contents of natural radium-226 and lead-210 in foods produced within the Russian territory
}

\author{
N. K. Shandala, N. Ya. Novikova, A. V. Titov, A. A. Filonova \\ \& V. A. Seregin \\ Burnasyan Federal Medical Biophysical Centre, Russia
}

\begin{abstract}
Dynamical examination of contents of the observed natural radionuclides in prime foodstuffs demonstrated their relative stability. Generally, ${ }^{210} \mathrm{~Pb}$ and ${ }^{226} \mathrm{Ra}$ specific activities in foodstuffs depend upon the food type and options of agriculture management. Many-year researches show that average specific activities of ${ }^{210} \mathrm{~Pb}$ and ${ }^{226} \mathrm{Ra}$ for different foodstuffs vary over the range $0.04-0.15$ $\mathrm{Bq} / \mathrm{kg}$ and $0.02-0.08 \mathrm{~Bq} / \mathrm{kg}$. Soil dependence of ${ }^{210} \mathrm{~Pb}$ and ${ }^{226} \mathrm{Ra}$ contents in foodstuffs has not been revealed. Taking into account the food patterns of the Russian population, the highest intake of ${ }^{210} \mathrm{~Pb}$ and ${ }^{226} \mathrm{Ra}$ is due to ingestion of bread, meat and drinking water. Annual effective internal doses are about $50 \mu \mathrm{Sv} / \mathrm{a}$.
\end{abstract}

Keywords: natural radionuclides, foodstuffs, doses, ingestion, intake.

\section{Introduction}

Natural radionuclides are present in all environmental media to a certain degree. Radionuclides of ${ }^{238} \mathrm{U}$ and ${ }^{232} \mathrm{Th}$ series, half-lives of which is comparable with the Earth age, and their progenies in significant amounts present in the environment and in the human body.

External exposure to the human is mainly due to gamma radiation of ${ }^{238} \mathrm{U}$ and ${ }^{232} \mathrm{Th}$ series, and ${ }^{40} \mathrm{~K}$.

Among radioactive ${ }^{238} \mathrm{U}$ products, the most contribution into the natural background is due to ${ }^{226} \mathrm{Ra}$, its fission product ${ }^{222} \mathrm{Rn}$ (radon) and long-lived products of ${ }^{210} \mathrm{~Pb}$ and ${ }^{210} \mathrm{Po}$ decay, which precipitate on the surface of soil and make significant contribution into dose. 
Behavior of radionuclides uranium and thorium series in the biological system is different. ${ }^{226} \mathrm{Ra}$ and its radioactive products $\left({ }^{210} \mathrm{~Pb},{ }^{210} \mathrm{Po}\right)$ have the most migration abilities among natural radionuclides in the chain soil - vegetations, while ${ }^{238} \mathrm{U}$ and ${ }^{232} \mathrm{Th}$ - the least.

Accumulation of natural radionuclides in the productive parts of crop (kern (corn), edible roots) is less than that in vegetative organs and roots.

Some factors define accumulation of natural radionuclides by plants, the prime of which are their physical and chemical properties (5-38\%), soil-climatic features of regions $(22-47 \%)$ and biological special features of plants $(38-48 \%)$ [6].

Cultivation of soil reduces significantly dependence of radionuclide intakes upon soil-climatic conditions and physical and chemical properties of radionuclides in the chain "soil - plants" and, hence, in foodstuffs.

So, ${ }^{210} \mathrm{Po},{ }^{210} \mathrm{~Pb}$ and ${ }^{226} \mathrm{Ra}$ are practically important for the purposes of radiation hygiene, because they are contained in vegetation, water, foods of animal and vegetable origin and, respectively, transferred into the human organism via foods [1-3].

Therefore, these radionuclides are the most informative (indicative, reference) in the course of the observation of the natural radionuclide contents in foods and internal dose assessment in the human organism. Nevertheless, monitoring is reasonable to be performed of long-lived ${ }^{226} \mathrm{Ra}$ and ${ }^{210} \mathrm{~Pb}$.

\section{Contents of natural radionuclides in foodstuffs}

Analysis of ${ }^{210} \mathrm{~Pb}$ and ${ }^{226} \mathrm{Ra}$ contents in foodstuffs in Russia showed that there was no statistically valid difference in annual radionuclide contents.

Therefore, to assess ${ }^{210} \mathrm{~Pb}$ and ${ }^{226} \mathrm{Ra}$ contents in the prime foodstuffs we use the mean value for Russia, table 1 .

The findings show that contents of natural radionuclides in foodstuffs depend upon the type of product and the spread of ${ }^{210} \mathrm{~Pb}$ and ${ }^{226} \mathrm{Ra}$ specific activities is rather wide and reaches an order of a magnitude.

To clarify dependence of natural radionuclide contents in foodstuffs on the soil type, data on natural radionuclide contents in foodstuffs were being joined into some groups according to the prevailing types of soil, typical for the Russian areas and regions under monitoring. Regardless identification of regions with soddy-podzolic and chernozem-chestnut soils, levels of ${ }^{210} \mathrm{~Pb}$ and ${ }^{226} \mathrm{Ra}$ contents in foodstuffs at which is higher a bit, than at boggy and podzolic soils, no statistically valid dependence of natural radionuclide contents in foods upon the soil type has been revealed.

Table 2 includes calculation results of ratio between ${ }^{210} \mathrm{~Pb}$ and ${ }^{226} \mathrm{Ra}$ specific activities in foodstuffs obtained using results of the Russian mean specific activities for these radionuclides in each of four Russian regions with different types of soil: soddy-podzolic, podzolic, boggy, and chernozem. On average, the ratio values by the soil types show satisfactory compliance with the mean Russian values, table 2 . 
Table 1: $\quad$ Mean ${ }^{210} \mathrm{~Pb}$ and ${ }^{226} \mathrm{Ra}$ contents in foodstuffs in Russia, Bq/kg [1].

\begin{tabular}{|c|c|c|}
\hline Foods & ${ }^{210} \mathrm{~Pb}$ & ${ }^{226} \mathrm{Ra}$ \\
\hline Bread & $\begin{array}{c}0.10 \\
0.01-0.67 * \\
(236)^{* *}\end{array}$ & $\begin{array}{c}0.05 \\
0.002-0.5 \\
(229)\end{array}$ \\
\hline Milk & $\begin{array}{c}0.05 \\
0.01-0.35 \\
(342)\end{array}$ & $\begin{array}{c}0.02 \\
0.001-0.15 \\
(312) \\
\end{array}$ \\
\hline Meat: beef & $\begin{array}{c}0.15 \\
0.01-0.36 \\
(5)\end{array}$ & $\begin{array}{c}0.08 \\
0.002-0.15 \\
(6)\end{array}$ \\
\hline Fish & $<0.01-0.44$ & $0.03-0.25$ \\
\hline Potato & $\begin{array}{c}0.07 \\
0.01-0.35 \\
(143) \\
\end{array}$ & $\begin{array}{c}0.03 \\
0.001-0.3 \\
(159) \\
\end{array}$ \\
\hline Cabbage & $\begin{array}{c}0.04 \\
0.001-0.48 \\
(96) \\
\end{array}$ & $\begin{array}{c}0.02 \\
0.001-0.4 \\
(120) \\
\end{array}$ \\
\hline Beet + Carrot & $\begin{array}{c}0.10 \\
0.002-0.34 \\
(38)\end{array}$ & $\begin{array}{c}0.03 \\
0.001-0.2 \\
(29) \\
\end{array}$ \\
\hline Drinking water & $\begin{array}{c}0.04 \\
0.001-0.2 \\
(83)\end{array}$ & $\begin{array}{c}0.02 \\
0.001-0.36 \\
(390)\end{array}$ \\
\hline
\end{tabular}

Table 2: $\quad$ Ration between ${ }^{210} \mathrm{~Pb}$ and ${ }^{226} \mathrm{Ra}$ specific activities in foodstuffs in Russia, ${ }^{210} \mathrm{~Pb} /{ }^{226} \mathrm{Ra}$ (quotas).

\begin{tabular}{|c|c|c|}
\hline Foodstuff & $\begin{array}{c}{ }^{210} \mathrm{~Pb} /{ }^{226} \mathrm{Ra} \text { on average } \\
\text { over Russia }\end{array}$ & $\begin{array}{c}{ }^{110} \mathrm{~Pb} /{ }^{226} \mathrm{Ra}, \text { mean value } \\
\text { by the soil types }\end{array}$ \\
\hline Bread & 1.9 & 1.9 \\
\hline Milk & 2.3 & 2.7 \\
\hline Potato & 2.3 & 1.9 \\
\hline Vegetables & 3.0 & 2.1 \\
\hline Fish & 2.2 & - \\
\hline Meat & 1.8 & 5.0 \\
\hline
\end{tabular}

Generally, ${ }^{210} \mathrm{~Pb}$ content is higher in all products (the ratio ${ }^{210} \mathrm{~Pb} /{ }^{226} \mathrm{Ra}$ values vary over the range from 1.0 to 9.0 ).

Study of materials on ${ }^{210} \mathrm{~Pb}$ and ${ }^{226} \mathrm{Ra}$ contents in foodstuffs over different years and at the areas with different types of soil allows further use the mean Russian data in calculation of intake and effective internal doses. 


\section{Consumption and intake of natural radionuclides via foodstuffs by the population of Russia}

Analysis of food ingestion in the home economics (all households), according to data of the Federal state statistic service over the period 2003-2006 showed that the food ration of the Russian population remained stable in terms of mass of its component (particular foodstuffs) [4].

Data on per capita food intake by the Russian population [5] are used in assessment of internal doses due to radionuclide intakes via the food ration. In the course of analysis, the frame of food ration on the prime 7 food groups has been developed indicating their ingestion in $\mathrm{kg} /$ day units.

Table 3 deals with ingestion of the particular foodstuffs by the population of the Russian Federation (RF), both per capita intake and intake by urban and farm adults separately.

Table 3: $\quad$ Ingestion of particular foodstuffs by the RF population, $\mathrm{kg} / \mathrm{a}$.

\begin{tabular}{|l|c|c|c|}
\hline \multicolumn{1}{|c|}{ Foods } & $\begin{array}{c}\text { On average per } \\
\text { capita }\end{array}$ & Urban citizen & $\begin{array}{c}\text { Farm } \\
\text { citizen }\end{array}$ \\
\hline $\begin{array}{l}\text { Bread and bread } \\
\text { products }\end{array}$ & 146.5 & 134.6 & 179.3 \\
\hline Milk and dairy & 144.4 & 138.9 & 156.7 \\
\hline Potato & 86.3 & 78.7 & 107.0 \\
\hline $\begin{array}{l}\text { Vegetables and } \\
\text { melons }\end{array}$ & 83.9 & 83.3 & 85.6 \\
\hline $\begin{array}{l}\text { Meat and meat } \\
\text { products }\end{array}$ & 60.7 & 62.8 & 55.0 \\
\hline Fish and fish products & 14.2 & 14.3 & 13.9 \\
\hline Fruits and berries & 35.3 & 37.8 & 29.3 \\
\hline Mushrooms & 1.0 & 1.0 & 1.0 \\
\hline Drinking water & 511.0 & 511.0 & 511.0 \\
\hline
\end{tabular}

Table 4: $\quad{ }^{210} \mathrm{~Pb}$ and ${ }^{226} \mathrm{Ra}$ intake by the population of Russia, Bq/a.

\begin{tabular}{|l|c|c|c|c|c|c|}
\hline \multirow{2}{*}{ Foods } & \multicolumn{2}{|c|}{ Per capita } & \multicolumn{2}{c|}{ Urban citizens } & \multicolumn{2}{c|}{ Farm citizens } \\
\cline { 2 - 7 } & ${ }^{210} \mathrm{~Pb}$ & ${ }^{226} \mathrm{Ra}$ & ${ }^{210} \mathrm{~Pb}$ & ${ }^{226} \mathrm{Ra}$ & ${ }^{210} \mathrm{~Pb}$ & ${ }^{226} \mathrm{Ra}$ \\
\hline Bread & 13.2 & 7.0 & 12.1 & 6.5 & 16.2 & 8.60 \\
\hline Milk & 6.5 & 2.8 & 6.3 & 2.8 & 7.0 & 3.13 \\
\hline Potato & 6.0 & 2.6 & 5.5 & 2.4 & 7.49 & 3.21 \\
\hline $\begin{array}{l}\text { Vegetables and } \\
\text { melons }\end{array}$ & 5.3 & 2.1 & 5.2 & 2.1 & 5.39 & 2.14 \\
\hline Meat & 9.1 & 4.9 & 9.4 & 5.2 & 8.25 & 4.51 \\
\hline Fish & 2.1 & 1.0 & 2.2 & 1.0 & 2.1 & 1.0 \\
\hline Drinking water & 17.9 & 8.7 & 17.9 & 8.7 & 17.9 & 8.7 \\
\hline Gross intake & 60.2 & 29.2 & 58.6 & 28.5 & 64.3 & 31.2 \\
\hline
\end{tabular}


As drinking water is important for uranium and radium series intake, it is included into intake assessment via the full ration, and the intake value of 1.4 $1 /$ day is accepted for all groups of population.

Data on natural radionuclide contents in foodstuffs (table 1) and on ingestion of the particular foods by the population of Russia (table 3) were used to calculate ${ }^{210} \mathrm{~Pb}$ and ${ }^{226} \mathrm{Ra}$ intake via foods per capita and for farm and urban population. Table 4 includes the calculated results. Here, ${ }^{210} \mathrm{~Pb}$ and ${ }^{226} \mathrm{Ra}$ contents in water are 0.035 and $0.017 \mathrm{~Bq} / 1$, respectively (table 1).

Table 4 shows that bread and drinking water have the highest ${ }^{210} \mathrm{~Pb}$ and ${ }^{226} \mathrm{Ra}$ intakes.

\section{Doses induced by natural radionuclides}

Table 5 show effective internal doses to the population of Russia due to ${ }^{210} \mathrm{~Pb}$ and ${ }^{226} \mathrm{Ra}$ intake via the food ration.

With the purpose of comparison, tables 6 and 7 include intakes and doses induced by ${ }^{137} \mathrm{Cs}$ and ${ }^{90} \mathrm{Sr}$. Mean ${ }^{90} \mathrm{Sr}$ and ${ }^{137} \mathrm{Cs}$ values for foods in Russia were used in calculations, table 8 .

Table 5: $\quad$ Effective internal doses induced by ${ }^{210} \mathrm{~Pb}$ and ${ }^{226} \mathrm{Ra}$ intaking by the $\mathrm{RF}$ population via foods, $\mu \mathrm{Sv} / \mathrm{a}$.

\begin{tabular}{|c|c|c|c|}
\hline $\begin{array}{c}\text { Dose induced } \\
\text { by }\end{array}$ & $\begin{array}{c}\text { On average to a } \\
\text { person }\end{array}$ & To urban citizen & To farm citizen \\
\hline${ }^{210} \mathrm{~Pb}$ & 41.5 & 40.5 & 44.4 \\
\hline${ }^{226} \mathrm{Ra}$ & 8.2 & 8.0 & 8.7 \\
\hline Total & 49.7 & 48.5 & 53.1 \\
\hline
\end{tabular}

Table 6: $\quad{ }^{137} \mathrm{Cs}$ and ${ }^{90} \mathrm{Sr}$ intake by the population of Russia, Bq/a.

\begin{tabular}{|l|c|c|c|c|c|c|}
\hline \multirow{2}{*}{ Foods } & \multicolumn{2}{|c|}{$\begin{array}{c}\text { On average to a } \\
\text { person }\end{array}$} & \multicolumn{2}{c|}{ To urban citizen } & \multicolumn{2}{c|}{$\begin{array}{c}\text { To farm } \\
\text { citizen }\end{array}$} \\
\cline { 2 - 7 } & ${ }^{137} \mathrm{Cs}$ & ${ }^{90} \mathrm{Sr}$ & ${ }^{137} \mathrm{Cs}$ & ${ }^{90} \mathrm{Sr}$ & ${ }^{137} \mathrm{Cs}$ & ${ }^{90} \mathrm{Sr}$ \\
\hline Bread & 205.2 & 19.0 & 188.4 & 17.5 & 251.0 & 23.3 \\
\hline Milk & 101.0 & 17.3 & 97.2 & 16.2 & 109.7 & 18.8 \\
\hline Potato & 60.4 & 6.9 & 55.1 & 6.3 & 74.9 & 8.6 \\
\hline $\begin{array}{l}\text { Vegetables and } \\
\text { melons }\end{array}$ & 2.5 & 7.6 & 2.5 & 7.5 & 2.6 & 7.7 \\
\hline Meat & 18.2 & 3.6 & 18.8 & 3.8 & 16.5 & 3.3 \\
\hline Fish & 2.6 & 10.9 & 2.8 & 11.0 & 2.5 & 10.7 \\
\hline Fruits and berries & 1.4 & 4.2 & 1.5 & 4.5 & 1.8 & 3.5 \\
\hline Mushrooms & 39.0 & 3.7 & 39.0 & 3.7 & 39.0 & 3.7 \\
\hline Dinking water & 0.5 & 1.0 & 0.5 & 1.0 & 0.5 & 1.0 \\
\hline Gross intake & 430.8 & 74.3 & 405.3 & 71.5 & 497.9 & 80.6 \\
\hline
\end{tabular}


Table 7: $\quad$ Doses induced by ${ }^{137} \mathrm{Cs}$ and ${ }^{90} \mathrm{Sr}$ intaking by the RF population via foods on average to a person, $\mu \mathrm{Sv} / \mathrm{a}$.

\begin{tabular}{|c|c|c|c|}
\hline $\begin{array}{c}\text { Dose induced } \\
\text { by }\end{array}$ & $\begin{array}{c}\text { On average to a } \\
\text { person }\end{array}$ & To urban citizen & To farm citizen \\
\hline${ }^{90} \mathrm{Sr}$ & 2.1 & 2.0 & 2.3 \\
\hline${ }^{137} \mathrm{Cs}$ & 5.6 & 5.3 & 6.5 \\
\hline Total & 7.7 & 7.3 & 8.8 \\
\hline
\end{tabular}

Table 8: $\quad$ Average ${ }^{137} \mathrm{Cs}$ and ${ }^{90} \mathrm{Sr}$ contents in foods in Russia, Bq/ kg, [1].

\begin{tabular}{|l|c|c|}
\hline \multicolumn{1}{|c|}{ Foods } & ${ }^{137} \mathrm{Cs}$ & ${ }^{90} \mathrm{Sr}$ \\
\hline Bread & $1.4 \pm 0.03$ & $0.13 \pm 0.03$ \\
\hline Milk & $0.7 \pm 0.04$ & $0.12 \pm 0.01$ \\
\hline Potato & $0.7 \pm 0.03$ & $0.08 \pm 0.01$ \\
\hline $\begin{array}{l}\text { Vegetables and } \\
\text { melons }\end{array}$ & $0.03 \pm 0.01$ & $0.09 \pm 0.01$ \\
\hline Meat & $0.3 \pm 0.03$ & $0.06 \pm 0.02$ \\
\hline Fish & $0.18 \pm 0.03$ & $0.77 \pm 0.01$ \\
\hline $\begin{array}{l}\text { Fruits and garden } \\
\text { berries }\end{array}$ & $0.04(0.10)^{*}$ & $0.12(0.19)$ \\
\hline Wild berries & $18.0(40.0)$ & $0.33(0.80)$ \\
\hline Mushrooms & $39.0(270.0)$ & $3.7(36.0)$ \\
\hline Drinking water & 0.001 & 0.002 \\
\hline Note: $*$ - in parentheses - maximum value & \\
\hline
\end{tabular}

Table 9: $\quad$ Percentage contribution of the main dose-forming radionuclides into internal dose to the population of Russia, $\%$.

\begin{tabular}{|c|c|c|c|}
\hline $\begin{array}{c}\text { Dose induced } \\
\text { by }\end{array}$ & $\begin{array}{c}\text { On average to a } \\
\text { person }\end{array}$ & To urban citizen & To farm citizen \\
\hline${ }^{210} \mathrm{~Pb}$ & 72.0 & 73.0 & 72.0 \\
\hline${ }^{226} \mathrm{Ra}$ & 14.0 & 14.0 & 14.0 \\
\hline${ }^{90} \mathrm{Sr}$ & 4.0 & 4.0 & 4.0 \\
\hline${ }^{137} \mathrm{Cs}$ & 10.0 & 9.0 & 11.0 \\
\hline Total & 100 & 100 & 100 \\
\hline
\end{tabular}

Calculations show that internal doses due to intake of natural radionuclides via foods by the population of Russia can be assessed at the level of about $50 \mu \mathrm{Sv} / \mathrm{a}$. Here, effective internal dose induced by ${ }^{210} \mathrm{~Pb}$ intake is 5 times higher than dose induced by ${ }^{226} \mathrm{Ra}$. The mentioned values are about 6 times higher than effective doses due to ${ }^{90} \mathrm{Sr}$ and ${ }^{137} \mathrm{Cs}$ intakes via the food ration.

Total dose induced by ${ }^{90} \mathrm{Sr}$ and ${ }^{137} \mathrm{Cs}$ varies from $7.3 \mu \mathrm{Sv} / \mathrm{a}$ (to the ran citizen) to $8.8 \mu \mathrm{Sv} / \mathrm{a}$ (to the farm citizen). 
Table 9 shows the percentage contribution of the main dose-forming radionuclides (natural and man-made) into internal dose to the population of Russia due to ingestion of foods.

Table 9 shows that quota of natural radionuclides in comparison with manmade radionuclide is much higher: the percentage contribution into gross ${ }^{210} \mathrm{~Pb}$ and ${ }^{226} \mathrm{Ra}$ dose is $72 \%$ and $14 \%$, respectively.

External exposure to the public [7] due to natural radionuclides containing in soil being calculated taking into account time of staying outdoors and in dwellings, is $350 \mu \mathrm{Sv} / \mathrm{a}$, which is $87,5 \%$ of gross internal and external dose (table 10).

Table 10: Effective internal and external ${ }^{210} \mathrm{~Pb}$ and ${ }^{226} \mathrm{Ra}$ induced doses to the population of Russia, $\mu$ Sv/a.

\begin{tabular}{|c|c|c|c|}
\hline $\begin{array}{c}\text { Dose induced } \\
\text { by }\end{array}$ & $\begin{array}{c}\text { On average to a } \\
\text { person }\end{array}$ & To urban citizen & To farm citizen \\
\hline${ }^{210} \mathrm{~Pb}$ & 41.5 & 40.5 & 44.4 \\
\hline${ }^{226} \mathrm{Ra}$ & 8.2 & 8.0 & 8.7 \\
\hline Total & $49.7(12.5 \%)$ & $48.5(14.5 \%)$ & $53.1(11.4 \%)$ \\
\hline $\begin{array}{c}\text { External due } \\
\text { to natural } \\
\text { radionuclides }\end{array}$ & $350.0(87.5 \%)$ & $286.0(85.5 \%)$ & $414.0(88.6 \%)$ \\
\hline $\begin{array}{c}\text { Internal }+ \\
\text { external }\end{array}$ & 399.7 & 334.5 & 467.1 \\
\hline
\end{tabular}

The mentioned data confirm that contribution of internal exposure due to natural radionuclides into total dose to the public of Russia is only $11-14 \%$ of gross internal and external dose, so, regulation of natural radionuclides in foods is unreasonable.

\section{Conclusion}

The majority of arguments found in the course of this work do not confirm the necessity of development of the particular numerical values of permissible specific activities of natural radionuclides for the prime types of foods. Doses due to internal exposure of natural radionuclides obtained in this work are about twice lower than average over-world data $(50 \mu \mathrm{Sv} / \mathrm{a}$ in comparison with $120 \mu \mathrm{Sv} / \mathrm{a})$.

Nevertheless, having in mind that doses due to internal exposure due to ${ }^{210} \mathrm{~Pb}$ and ${ }^{226} \mathrm{Ra}$ intakes are much high than those of man-made radionuclides $\left({ }^{90} \mathrm{Sr}\right.$ and ${ }^{137} \mathrm{Cs}$ ): percentage contribution into gross dose of ${ }^{210} \mathrm{~Pb}$ and ${ }^{226} \mathrm{Ra}$ is $72 \%$ and $14 \%$, respectively, now, monitoring of natural radionuclide contents should be performed prime foods. Such kind of monitoring must be carried out within social hygienic monitoring, which is the prime mechanism regulating sanitary and epidemiological prosperity of the public, as well as within radiation hygienic certification of regions. 


\section{References}

[1] Sources and effects of ionizing radiation. UNSCEAR Report 2000. With scientific appendices. V.1 Sources. part.2. L A Ilyin and S P Yaroshenko editors. RADEKON: Moscow, 2002.

[2] Alexakhin R M, Arkhipov N P, Barkhoudarov R M ea. Heavy natural radionuclides in biosphere: migration and biological impact on populations and bio-geo-cenosis, Nauka: Moscow, 1990.

[3] Karpin V A, Kostryukova N K, Goudkov A B. Radiation exposure of radon and its daughter products to the human //Hygiene and sanitary, 4 , p. 38-40, 2005.

[4] Ingestion of foods from domestic husbandries over 2003. (according to outcomes of selective inspection of household budgets), Goscomstat of Russia: Moscow, 2004.

[5] Assessment of individual effective doses to the public due to natural radiation sources. Methodic guidance 2.6.1.1088-02. Minzdrav of Russia: Moscow, p. 22, 2002.

[6] Drichko V F. Environmental Behavior of Heavy Natural Radionuclides //Results of science and engineering. Radiation biology, 4, 1983.

[7] Radiation safety assurance for the land-using (radiation and hygienic aspects), Federal Centre of Gossanepidnadzor at Minzdrav of Russia: Moscow, 2005. 